\title{
PENGARUH MEDIA “QUIZIZZ” DALAM PEMBELAJARAN DARING TERHADAP HASIL BELAJAR BIOLOGI SISWA
}

\author{
Nurul Sukmah ${ }^{1}$ \\ Universitas Muslim Maros, Snuru1704@gmail.com \\ Pertiwi Indah Lestari ${ }^{2}$, Rizki Amalia Nur $^{3}$ \\ Universitas Muslim Maros, pertiwi@umma.ac.id, rizkiamalianur@gmail.com
}

\begin{abstract}
ABSTRAK
Penelitian ini bertujuan untuk mengetahui pengaruh penggunaan media Quizizz. terhadap hasil belajar biologi siswa. Penelitian ini menggunakan metode kuasi eksperimen dengan desain Nonequivalent Control Group Design. Pengambilan sampel dengan teknik Purpose sampling, sampel dalam penelitian ini adalah siswa dari kelas yaitu X MIPA 4 dan X MIPA 1. Pada pembelajaran materi perubahan lingkungan, satu kelas diajar dengan menggunakan media Quizizz terkhusus pada penutup pembelajaran, sedangkan kelas lainnya diberikan tugas dalam bentuk resume pada penutup pembelajarannya. Instrumen yang digunakan berupa tes pilihan ganda sebanyak 20 item yang telah divalidasi. Teknik analisis data menggunakan uji Shapiro-wilk untuk uji normalitas, dan univariate of variance untuk uji homogenitas. Selanjutnya untuk uji hipotesis menggunakan uji $T$ Test, sedangkan untuk peningkatan hasil belajar menggunakan uji N-gain. Setalah dilakukan pengujian diperoleh perbandingan peningkatan hasil belajar lebih tinggi pada kelas eksperimen dibandingkan kelas kontrol sedangkan untuk uji hipotesis diperoleh $t_{\text {hitung }}$ sebesar 4,399 $>t_{\text {tabel }}$ 1,697. Maka dapat disimpulkan terdapat pengaruh penggunaan media Quizizz terhadap hasil belajar biologi siswa kelas X MIPA SMAN 3 Maros.
\end{abstract}

\begin{abstract}
This study aims to determine the effect of using Quizizz media on student biology learning outcomes. This study uses a quasi-experimental method with the design of the Noneequivalent Control Group Design. Sampling using the Purpose sampling technique, the samples in this study were students from classes X MIPA 4 and X MIPA 1. In learning environmental change material, one class was taught using Quizizz media especially at the closing of the lesson, while the other class was given assignments in the form of a resume. at the end of the lesson. The instrument used is a multiple choice test with 20 items that have been validated. The data analysis technique used ShapiroWilk test for normality test, and univariate of variance for homogeneity test. Furthermore, to test the hypothesis using the $\mathrm{T}$ test, while to improve learning outcomes using the N-gain test. After testing the results of increasing learning outcomes, the experimental class was higher than the control class, while for hypothesis testing, it was obtained that tcount was $4.399>$ ttable 1.697. So it can be said that there is an effect of using Quizizz media on the learning outcomes of biology class X MIPA SMAN 3 Maros.
\end{abstract}

Kata kunci: Quizizz, hasil belajar biologi 


\section{PENDAHULUAN}

Di awal tahun 2020, dunia dikejutkan dengan adanya wabah yang berasal dari suatu virus yang bernama Corona Virus atau sering disebut dengan Covid-19. Virus ini menular dengan sangat cepat dan telah menyebar ke hampir semua negara, termasuk Indonesia, hanya dalam waktu beberapa bulan. Wabah ini sangat berdampak di berbagai sektor kehidupan salah satunya pada bidang pendidikan. Sebagai upaya memutus mata rantai penyebaran virus Covid-19 pemerintah menganjurkan untuk menutup kegiatan pembelajaran di sekolah dan menerapkan pembelajaran daring (Online). Pembelajaran secara daring (Online) merupakan cara baru dalam proses pembelajaran yang memanfaatkan teknologi khususnya internet dalam prosesnya. Pembelajaran ini sepenuhnya bergantung terhadap akses jaringan internet (Rigianti, 2020). Proses pembelajaran ini mengharuskan pendidik untuk bisa memanfaatkan teknologi yang ada guna menciptakan pembelajaran yang efektif dan menarik agar memotivasi siswa untuk belajar, serta diharapkan kognitif siswa terhadap hasil belajar dapat mudah tercapai. meskipun dalam proses pembelajaran jarak jauh atau daring. Namun yang terjadi di lapangan, pendidik masih
Kesulitan dalam memanfaatkan teknologi dalam pembelajaran. Dimana pada umunya pendidik hanya membagikan materi dalam bentuk File Word maupun dalam bentuk Power Point yang kemudian memberikan penugasan kepada siswa. Tugas yang diberikan biasanya berupa rangkuman-rangkuman materi yang telah diberikan sebelumnya.

Hal ini tentu saja membuat proses pembelajaran tidak berjalan sesuai dengan tahapan-tahapan dalam pelaksanaan pembelajaran dan membuat pembelajaran tersebut tidak interaktif dan terkesan pasif. Untuk mengatasi hal tersebut dibutuhkan pemanfaatan media yang dapat membantu siswa dalam proses pembelajaran.

Tujuan dari penggunaan media sendiri yaitu untuk menumbuhkan semangat belajar siswa agar dapat mengikuti pembelajaran dengan baik, ini sejalan dengan pendapat Arsyad (dalam Irawati, 2018) yang mengatakan bahwa media pembelajaran adalah segala sesuatu yang digunakan untuk menyampaikan pesan atau informasi dalam proses belajar mengajar sehingga dapat merangsang perhatian dan semangat siswa dalam belajar. Penerapan media yang cocok dan menarik merupakan solusi dalam mengatasi 
permasalahan yang dialami selama kegiatan pembelajaran daring.

Ada banyak sekali media yang bisa dimanfaatkan dalam proses pembelajaran secara daring. Salah satu aplikasi daring yang berbasis game edukasi adalah Quizizz. Quizizz merupakan sebuah platfrom yang bisa diakses melalui website serta dapat digunakan siswa dikelas maupun diluar kelas. Aplikasi Quizizz ini dilengkapi dengan avatar, karakter tema, serta music yang bisa dijadikan alat hiburan bagi siswa saat proses belajar atau saat mengerjakan soal latihan. Quizizz juga mampu memicu persaingan antara siswa karena dengan aplikasi ini mampu memberi peringkat secara otomatis saat siswa selesai mengerjakan kuis atau soal latihan. Sehingga memotivasi siswa untuk lebih aktif dalam proses pembelajaran dan meningkatkan fokus dalam mengerjakan soal latihan atau kuis. Penelitian ini bertujuan untuk mengetahui bagaimana pengaruh media Quizizz dalam pembelajaran daring dan adakah perbedaan hasil belajar siswa setelah menggunakan media tersebut. Sehingga diharapkan dapat memberikan informasi tambahan terkait media pembelajaran dan memberikan motivasi bagi pendidik dalam memanfaatkan teknologi dalam pembelajaran.

\section{METODE PENELITIAN}

Jenis penelitian yang digunakan adalah penelitian kuantitatif dengan metode Quasy Experiment. sebagaimana penelitian ini membandingkan dua kelas yang diberi perlakuan dengan menggunakan media Quizizz dan yang tidak menggunakan media Quizizz, kemudian membandingkan hasil dari kedua perlakuan yang berbeda. Hal ini bertujuan untuk mengetahui perbedaan hasil belajar siswa setelah diadakannya perlakuan. Desain penelitian ini menggunakan Nonequivalent Control Group Design. Dalam desain ini terdapat dua kelompok yang dipilih tidak secara random (acak). Dua kelompok ini akan diberikan pretest kemudian perlakukan dan posttes. Pengaruh treatment dianalisis dengan uji beda, menggunakan statistic t-test misalnya apabila terdapat perbedaan yang signifikan antara kelompok eksperimen dan kelompok kontrol, maka perlakuan yang diberikan berpengaruh secara signifikan. Berikut merupakan 
Gambar 1 : Nonequivalent control group design

\begin{tabular}{|llll|}
\hline KE & O1 & $\mathrm{X}_{1}$ & $\mathrm{O}_{2}$ \\
KK & $\mathrm{O}_{3}$ & $\mathrm{X}_{2}$ & $\mathrm{O} 4$ \\
\hline
\end{tabular}

Sumber: Desain Penelitian (Sugiyono, 2015)

Keterangan:

$\begin{array}{ll}\mathrm{KE} & =\text { Kelas Eksperimen } \\ \mathrm{KK} & =\text { Kelas Kontrol } \\ \mathrm{O} 1 \text { dan O3 } & =\text { Pretest kelas } \\ & \text { eksperimen dan kelas } \\ & \text { kontrol } \\ \text { O2 dan O4 } & =\text { Posttest kelas } \\ & \text { eksperimen dan kelas } \\ & \text { kontrol } \\ & =\text { Perlakuan dengan } \\ \text { X1 } & \text { menggunakan media } \\ & \text { Quizizz } \\ & =\text { Perlakuan tanpa } \\ \text { X2 } & \text { menggunakan media } \\ & \text { apapun }\end{array}$

Populasi penelitian ini adalah seluruh siswa kelas X MIPA SMAN 3 Maros. Dimana total kelas $\mathrm{X}$ MIPA sebanyak 7 kelas (X MIPA 1 sampai X MIPA 7) dengan jumlah setiap kelas sebanyak 33 orang. Adapun pada penelitian ini peneliti menggunakan teknik pengambilan sampel yaitu Purpose sampling. Purpose sampling merupakan teknik pengambilan sampel yang dilakukan dengan melihat pertimbangan tertentu. Purpose sampling dugunakan apabila sasaran sampel yang diteliti telah memiliki karakteristik tertentu sehingga tidak mungkin diambil sampel lain yang tidak memenuhi karakteristik yang telah ditetapkan.
Dalam penentuan sampel ini peneliti mendapatkan kelas yang akan dijadikan sampel penelitian atas pertimbangan telah dipilihkan oleh guru mata pelajaran biologi dan kelas yang terpilih mempunyai kemampuan yang homogen. Adapun sampel yang disarankan oleh guru mata pelajaran biologi SMAN 3 Maros adalah kelas X MIPA 1 dan MIPA 4.

Adapun teknik pengumpulan datanya data dalam penelitian ini yaitu berupa tes dan dokumentasi. Tesnya berupa tes pretest dan posttest. Tes awal (Pretetst) diberikan sebelum proses pembelajaran berlangsung, ini bertujuan untuk mengetahui sejauh mana kemampuan awal siswa. Tes akhir (Posttest) diberikan setalah proses pembelajaran berlangsung, ini bertujuan untuk mengetahui keberhasilan penggunaan media pembelajaran Quizizz. pada mata pelajaran Perubahan Lingkungan. Adapun jenis tes yang digunakan dalam penelitian ini berupa tes pilihan ganda, sedangkan instrumen yang digunakan berupa soal tes pilihan ganda masing-masing sebanyak 25 soal yang nantinya akan divalidasi dan dikumpulkan 20 soal yang benar-benar valid untuk digunakan. Sebelum digunakan instrumen tes di uji validasi 
dan uji reliabilitas. Validasi soal terdiri dari validasi butir soal dan validasi soal ahli materi. Validasi butir soal dilakukan pada 20 siswa kelas XI MIPA 2 sebagai sampel uji coba.

\section{HASIL DAN PEMBAHASAN}

Perlakuan penelitian ini dilakukan selama 5 kali pertemuan dengan 2 pertemuan untuk tes awal dan uji tes akhir. Adapun materi biologi yang diajarkan pada penelitian ini adalah materi perubahan lingkungan. 2 kelas sebagai sampel penelitian, yaitu kelas $\mathrm{X}$ MIPA 4 sebagai kelas eksperimen yang diajarkan dengan menggunakan media Quizizz terkhusus pada penutup pembelajaran dan X MIPA 1 sebagai kelas kontrol.

Untuk melihat peningkatan hasil belajar antar kedua kelompok kelas tersebut dilakukan pengujian $\mathrm{N}$-gain $\mathrm{Uji}$ n-gain dapat digunakan untuk mengetahui peningkatan nilai masingmasing siswa dan rata-rata $\mathrm{N}$-gain kelas setelah diberikan perlakuan.

Tabel 1. Hasil uji N-Gain

\begin{tabular}{cccc}
\hline Kelas & Pretest & Posttest & $\begin{array}{r}\text { N } \\
\text { Gain }\end{array}$ \\
\hline Kontrol & 50,91 & 75,78 & 0,51 \\
Eksperimen & 50,45 & 86,21 & 0,70 \\
& & \\
\hline
\end{tabular}

Berdasarkan tabel 1, dapat diketahui bahwa terdapat peningkatan nilai baik pada kelas kontrol maupun kelas eksperimen. Dimana pada kelas kontrol peningkatan nilainya berada pada kategori sedang dengan skor N Gain 0,51 sedangkan pada kelas eksperimen peningkatan nilainya berada pada kategori tinggi dengan skor N Gain 0,70.

Selanjutnya untuk melihat hasil ketuntasan siswa dengan kategori $\leq 75$ (Tidak tuntas) dan $\geq 75$ (Tuntas)

Tabel 2. Ketuntasan Hasil Belajar

\begin{tabular}{lccc}
\hline & Kategori & \multicolumn{2}{c}{ Kelas Kontrol } \\
\cline { 3 - 4 } & & Frekuensi & $\%$ \\
\hline$\leq \mathbf{7 5}$ & Tidak & 12 & $36 \%$ \\
& Tuntas & 21 & $64 \%$ \\
& Tuntas & & \\
\hline \multicolumn{3}{c}{ (Sumber: Data penelitian) }
\end{tabular}

Berdasarkan tabel 2 pada kelas kontrol ketuntasan siswa $\leq 75$ sebanyak 12 orang dengan presentase sebesar $36 \%$ dan 21 siswa lainnya berada pada kategori tuntas dengan presentase ketuntasan sebasar $64 \%$.

Tabel 3. Ketuntasan Hasil Belajar

\begin{tabular}{lccc}
\hline & Kategori & \multicolumn{2}{c}{ Kelas Eksperimen } \\
\cline { 3 - 4 } & & Frekuensi & $\%$ \\
\hline $\mathbf{5}$ & Tidak Tuntas & 1 & $3 \%$ \\
$\mathbf{7 5}$ & Tuntas & 32 & $97 \%$ \\
\hline $\mathbf{7 5}$ & & & \\
\hline \multicolumn{4}{c}{ (Sumber: Data penelitian) } \\
data pada tabel 3, pada hasil belajar siswa \\
pada & kelas eksperimen & dapat & dilihat
\end{tabular}


distribusi frekuensi ketuntasannya yang $\leq$ 75 sebanyak 1 orang siswa dengan presentase sebesar 3\% sedangkan 32 orang lainnya berada pada kategori tuntas dengan presentasi sebanyak $97 \%$.

Sebelum dilakukan pengujian hipotesis perlu dilakukan pemeriksaan terlebih dahulu terhadap data penelitian, yaitu uji normalitas dan uji homogen. Uji normalitas dilakukan pada keempat data yaitu pretest kelas kontrol dan eksperimen, serta data posttest kelas kontrol dan eksperimen. Adapun Uji normalitas dilakukan dengan menggunakan rumus Shapiro-Wilk untuk menguji signifikansi normalitas distribusi pada taraf signifikan $\alpha=0,05$.

Tabel 4. Hasil uji Normalitas

\begin{tabular}{lcc}
\hline Kelas & $\begin{array}{c}\text { Kolmogorov- } \\
\text { Smirnov }^{\mathbf{a}}\end{array}$ & $\begin{array}{c}\text { Shapiro- } \\
\text { Wilk }\end{array}$ \\
\hline Pretest Kontrol & 0.041 & 0,286 \\
\hline Posttes Kontrol & 0,173 & 0,350 \\
\hline $\begin{array}{l}\text { Pretest } \\
\text { Eksperimen }\end{array}$ & 0,111 & 0,239 \\
\hline $\begin{array}{l}\text { Posttes } \\
\text { Eksperimen }\end{array}$ & 0,124 & 0,210 \\
\hline \multicolumn{2}{c}{ (Sumber: Data penelitian) }
\end{tabular}

Berdasarkan uji normalitas dengan menggunakan Shapiro-Wilk pada tabel 1, diperoleh nilai signifikan sebesar 0,286 dan 0,350 untuk nilai pretest dan posttest pada kelas kontrol, sedangkan pada kelas eksperimen nilai signifikan yang diperoleh adalah 0,239 dan 0,210 untuk nilai pretest dan posttest. Jadi dapat disimpulkan bahwa sampel berdistribusi normal, karena seluruh data memiliki nilai signifikan yang lebih besar dari 0,05.

Uji homogenitas ini dilakukan dengan tujuan untuk mengetahui tingkat varians data pada hasil belajar siswa baik pada tes awal (pretest) maupun pada tes akhir (Posttest) kelas kontrol dan kelas eksperimen homogen/mempunyai varian yang sama atau tidak.

Tabel 5. Hasil uji Homogenitas

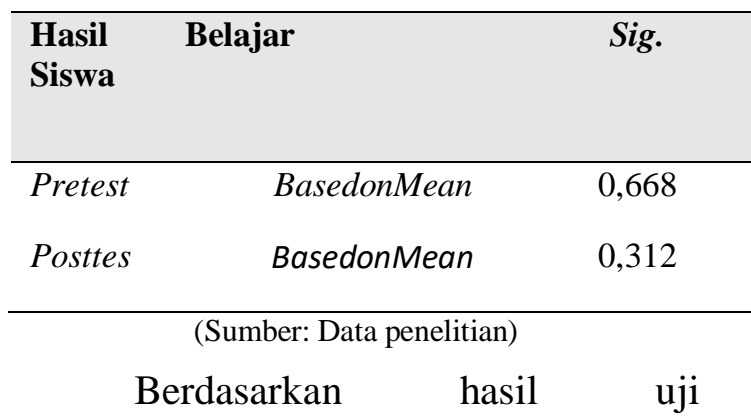

homogenitas pada tabel 2, diperoleh nilai signifikan sebesar 0,668 pada tes awal (Pretest), hal ini berarti 0,668>0,05. Sedangkan pada tes akhir (Posttest) diperoleh nilai signifikan sebesar 0,312 , hal ini berarti nilai signifikannya yaitu 0,312>0,05. Maka dapat disimpulkan bahwa seluruh data tersebut mempunya varians yang sama atau tidak terdapat perbedaan varians 1 dan varians 2 (sampel homogen).

Dalam penelitian untuk pengujian hipotesis digunakan statistika interferensial dengan bantuan SPSS versi 25 yaitu statistika uji $\mathrm{t}$ dalam hal ini uji 
Independent Sample $T$ Test. Adapun kriteria pengujiannya adalah $\mathrm{H}_{0}$ diterima dan $\mathrm{H}_{1}$ ditolak jika nilai $\mathrm{t}_{\text {hitung }}<\mathrm{t}_{\text {tabel, }}$, yang artinya tidak ada perbedaan antara dua perlakuan yang diberikan. Sedangkan sebaliknya, hipotesis $\mathrm{H}_{0}$ ditolak dan $\mathrm{H}_{1}$ diterima jika nilai $t_{\text {hitung }}>t_{\text {tabel, }}$ atau jika Sig $>\alpha$, maka $\mathrm{H}_{0}$ diterima dan jika $\mathrm{Sig}<$ $\alpha$, maka $\mathrm{H}_{0}$ ditolak.

Tabel 6. Hasil uji Hipotesis

\begin{tabular}{lcc}
\hline $\begin{array}{l}\text { Hasil Belajar } \\
\text { Siswa }\end{array}$ & thitung $_{\text {hig. (2-tailed) }}$ & \\
\hline Pretest & 0,054 & 0,957 \\
Posttes & 4,399 & 0,000 \\
\hline
\end{tabular}

(Sumber: Data penelitian)

Berdasarkan hasil pengelolaan data pada tabel 3, dengan menggunakan bantuan SPSS versi 25, diperoleh nilai pada uji $\mathrm{t}$ posttest setelah diberikan perlakuan diperoleh $t_{\text {hitung }}$ sebesar 4,399 dengan merujuk pada $t_{\text {tabel }}$ dengan taraf kepercayaan $95 \%(\alpha=0,05)$ dan $\mathrm{df}$ sebesar 64 diperoleh $t_{\text {tabel }}$ sebesar 1,697. Apabila dibandingkan $t_{\text {hitung }}$ dengan $t_{\text {tabel, }}$ maka diperoleh $t_{\text {hitung }}>t_{\text {tabel }}$ atau bisa dilihat juga pada nilai Sig (2-tailed) yang diperoleh yaitu sebesar $0,00<0,05$ dengan demikian $\mathrm{H}_{0}$ ditolak dan hipotesis $\mathrm{H}_{1}$ diterima. Dapat disimpulkan bahwa terdapat pengaruh yang signifikan pada hasil belajar siswa antara yang menggunakan media Quizizz terkhusus pada penutup pembelajaran daring dengan siswa yang hanya diberikan tugas dalam bentuk resume pada penutup pembelajaran.

Berdasarkan hasil penelitian menunjukkan bahwa pelaksanaan pembelajaran dengan menggunakan media Quizizz berpengaruh terhadap hasil belajar siswa hal ini bisa dilihat dengan adanya perbedaan hasil belajar siswa pada kedua kelas. Pada hasil pengujian hipotesis pretest siswa menunjukkan tidak adanya perbedaan yang signifikan antara kelas kontrol dan eksperimen. Sedangkan pada hasil pengujian hipotesis posttest siswa menunjukkan adanya perbedaan yang signifikan antara kelas kontrol dan eksperimen. Perbedaan tersebut menunjukkan bahwa pembelajaran dengan menggunakan media Quizizz terkhusus pada penutup pembelajaran daring berpengaruh terhadap hasil belajar siswa pada materi perubahan lingkungan. . Hal ini terbukti dengan diperoleh nilai rata-rata hasil belajar pada posttes kelas eksperimen sebesar 85,00. Sedangkan untuk kelas kontrol nilai rata-rata hasil belajar yang diperoleh sebesar 74,85. Hal ini menunjukkan bahwa ada perbedaan dalam tingkat kemampuan siswa, ketika siswa mengikuti suatu pembelajaran dengan menggunakan media yang sama, 
maka besarnya hasil belajar yang diperoleh kelas kontrol maupun kelas eksperimen akan sama atau seimbang.

Berdasarkan analisis deskriptif yang telah dilakukan, pada nilai pretest kelas Eksperimen menunjukkan rata-rata nilai yang diperoleh sebesar 50,45 dengan nilai minimum sebesar 30 dan nilai maksimumnya 75 . Sedangkan pada nilai posttest rata-rata nilai yang diperoleh adalah 85,00 dengan nilai minimum sebesar 65 dan nilai maksimumnya 100 . Dari analisis deskriptif tersebut diketahui peningkatan hasil belajar yang diperoleh pada kelas eksperimen berada pada kategori sedang dengan nilai $\mathrm{N}$-gain sebesar 0,70 .

Pada bagian ini akan menjawab rumusan masalah yang pertama tentang pengaruh media Quizizz terhadap hasil belajar siswa kelas X MIPA SMAN 3 Maros dengan menggunakan analisis statistik. Berdasarkan hasil analisis data tes akhir (posttest) menggunakan Independent Sampel t Test pada kedua kelompok kelas tersebut menunjukkan nilai $\operatorname{Sig}(2$-tailed $)<\alpha$ atau $0,000<0,05$. Artinya bahwa terdapat perbedaan yang signifikan pada hasil posttest atau hasil belajar akhir antara kedua kelas tersebut setelah diberikan perlakuan yang berbeda, yaitu pada kelas kontrol tetap diberikan pembelajaran secara daring tanpa menggunakan media Quizizz namun diberikan penugasan dalam bentuk rangkuman materi terkhusus pada penutup pembelajaran. Sedangkan pada kelas eksperimen diberikan pembelajaran secara daring dan penggunaan media Quizizz terkhusus pada penutup pembelajarannya.

Berdasarkan pengamatan peneliti terkait proses pembelajaran daring pada kelas kontrol berada pada taraf sedang hal ini ditandai dari kurangnya antusias siswa dalam proses pembelajaran dan masih banyak siswa yang tidak mengerjakan tugas tepat waktu dan lebih banyak menunda-nunda pengerjaan tugas yang diberikan dan bahkan ada yang enggan untuk mengerjakan. Sehingga pendidik kesulitan untuk mengetahui tingkat keberhasilan siswa dalam memahami materi yang diberikan. Sedangkan pada kelas eksperimen cukup tinggi hal ini dilihat dari banyaknya siswa yang ikut serta dalam mengerjakan kuis dengan Quizizz pada penutup pembelajaran, dengan menggunakan media Quizizz siswa diakomodasi untuk mengulang materi sehingga lebih mengerti materi yang diajarkan. Dalam pengerjaan menggunakan Quizizz, ketika siswa salah menjawab kuisnya, maka akan muncul 
jawaban yang benar, sehingga siswa dapat melakukan proses evaluasi terhadap jawabannya. Hal ini tentu saja memberikan stimulus bagi siswa untuk mengingat jawaban yang seharusnya sehingga dari hal tersebut siswa dapat lebih mengerti materi pada pertemuan hari itu. Dengan demikian dapat disimpulkan bahwa media Quizizz dapat memfasilitasi tercapainya salah satu tujuan dari kegiatan penutup yaitu kegiatan meninjau kembali, hal tersebut dapat mempermudah siswa dalam menerima dan memahami materi pelajaran. Hal ini sejalan dengan teori yang dikemukakan oleh Slameto (2010) bahwa alat pelajaran atau dalam hal ini media yang tepat digunakan dalam pembelajaran akan memperlancar atau mempermudah penerimaan bahan pelajaran yang diberikan kepada siswa.

Pada penelitian ini penggunaan Quizizz menggunakan jenis kuis langsung atau pendidik sebagai pemimpin dalam sesi kuis dengan mode klasik dimana dalam mode klasik ini siswa mengerjakan kuis dengan kecepatan mereka sendiri dan pendidik dapat melihat proses dan hasil pengerjaannya secara langsung, sehingga tingkat kecurangan dalam mengerjakan soal sangat rendah.
Namun ada beberapa hambatan yang ditemui dalam menggunakan media Quizizz ini, yaitu koneksi jaringan yang tiba-tiba terputus sehingga terkendala saat mengerjakan soal, meskipun begitu siswa yang telah masuk pada aplikasi Quizizz dan terkendala dalam pengerjaan soal karena koneksi jaringan yang tidak stabil, datanya tetap terinput masuk dan siswa dapat mengerjakan ulang soal saat jaringan mereka telah stabil.

Meskipun demikian penggunaan media Quizizz dirasa sangat cocok digunakan pada saat pembelajaran online (daring) di tengah masa pandemi seperti saat ini, karena dengan media ini dapat menciptakan suasana belajar yang menyenangkan tanpa harus menghilangkan atau mengurangi pemahaman siswa mengenai materi yang diajarkan hal ini dapat dilihat dari peningkatan hasil belajar siswa pada kelas eksperimen yang berada pada kategori tinggi dibandingkan dengan kelas kontrol.

Hasil penelitian ini juga didukung oleh penelitian Aluisius Suryo Nugroho (2020) dalam skripsinya yang berjudul "Implementasi Penggunaan Media Quizizz Pada Kegiatan Penutup Pelajaran Pengantar Akuntasi Materi Jurnal Penyesuaian Di Kelas X AAKL 2 SMK 
Negeri 1 Yogyakarta Tahun Pelajaran 2019/2020" dimana hasil penelitiannya yang ditinjau dari hasil prestasi belajar menunjukkan hasil yang sangat baik. Dimana media Quizizz membuat siswa lebih termotivasi untuk belajar kembali, karena dengan media ini siswa dapat mengetahui kemampuan mereka terkait materi yang telah dibahas.

Penelitian relevan lainya dari penelitian Unik Hanifa dkk (2020) dalam jurnalnya yang berjudul "Pemanfaatan Aplikasi Quizizz Sebagai Media Pembelajaran Ditengah Pandemi Pada Siswa SMA" menyatakan bahwa Quizizz menjadi alternatif dalam menyampaikan materi pembelajaran terhadap siswa dikarenakan media ini mampu menarik serta memotivasi cara kerja otak dan olah manajemen waktu.

\section{KESIMPULAN}

Berdasarkan hasil dari analisis data dan pembahasan yang ada, maka dapat disimpulkan sebagai berikut: Pada hasil belajar biologi siswa terdapat perbedaan peningkatan hasil belajar, dimana pada kelas eksperimen berada pada kategori tinggi sedangkan kelas kontrol termasuk dalam kategori sedang. Hasil uji t posttest siswa dengan diperoleh $\mathrm{t}_{\text {hitung }} 4,399>\mathrm{t}_{\text {tabel }} 1,697$ yang berarti $\mathrm{H}_{0}$ ditolak dan hipotesis $\mathrm{H}_{1}$ diterima. Sehingga disimpulkan bahwa terdapat pengaruh penggunaan media Quizizz terhadap hasil belajar biologi siswa. Quizizz dapat memberikan kelebihankelebihan tersendiri baik bagi siswa maupun bagi guru itu sendiri. Quizizz dapat melaksanakan evaluasi pembelajaran setiap hari dari rumah. Bisa juga dimanfaatkan untuk media pelaksanaan Penilaian Tengah Semester (PTS) dari rumah. Serta dapat pula dimanfaatkan untuk melaksanakan Ujian Akhir Semester (UAS) dari Rumah. Quizizz merupakan sebuah web tool untuk membuat permainan kuis interaktif yang digunakan dalam pembelajaran di kelas. Kuis interaktif yang dibuat memiliki hingga 4 pilihan jawaban termasuk jawaban yang benar dan dapat ditambahkan gambar ke latar belakang pertanyaan.

Quizizz dapat memberikan data dan statistik tentang hasil kinerja siswa secara langsung. Quizizz tidak hanya dapat dikerjakan saat pembelajaran di kelas saja, tetapi juga dapat dibuat soal untuk pekerjaan rumah (PR), sehingga dapat dimainkan kapan saja dan dimana saja oleh siswa asalkan tidak melebihi batas waktu yang sudah ditentukan. 
Dengan quizizz ini, siswa akan merasa ditantang, karena ada skor yang diperoleh dengan menjawab secara cepat dan tepat, kecepatan akan ada skor sendiri. Selain itu akan ada persaingan, karena quizizz langsung membuat ranking yang bersifat live antar peserta quizizz. Menyenangkan karena akan ada suasana musik untuk menyemangati, dan juga meme yang lucu serta menyemangati.

Kelebihan dari quizizz bagi siswa adalah siswa tidak dapat mencontek sesama temannya, karena soal yang diberikan kepada siswa satu dengan yang lainnya telah diacak. Soal bisa dibuat dengan ketentuan waktu tertentu yang membuat siswa tidak punya kesempatan untuk bertanya dengan orang sekitar atau melihat buku catatan miliknya. Setelah mengerjakan kuis, siswa dapat mengetahui rangking yang dia dapat dari keseluruhan siswa yang mengerjakan soal tersebut. tidak hanya itu, siswa juga mengetahui soal dan jawaban yang betul dari soal yang telah dikerjakannya.

Keuntungan quizizz bagi guru adalah akan ada grading otomatis, kemudian quiziz membuat analisis butir soal, yang semuanya dapat diunduh berupa file excel. Laporan cukup detail, setiap siswa akan dilaporkan jawaban benar-salahnya, serta prosentase pencapaian quiz untuk seluruh siswa. Selain itu sebenarnya, hasil quiz setiap siswa dapat diemail ke orang tua siswa.

\section{UCAPAN TERIMA KASIH}

Ucapan terima kasih yang sebesar-besarnya pada seluruh pihak yang terlibat dalam penelitian ini, semoga Allah SWT selalu memberkahi rahmatnya. Kepada kedua pembimbing saya yang telah meluangkan waktu serta tenaganya dalam membantu dan membimbing saya dalam menyelesaikan tugas akhir ini dan kepada unsur pimpinan FKIP UMMA yang telah meribakan wadah untuk menimba ilmu dan memberikan ruang untuk dapat melakukan penelitian ini.

\section{DAFTAR PUSTAKA}

Aluisus, S N. (2020). Implemetasi penggunaan media quizizz pada kegiatan penutup pelajaran pengantar akuntansi materi jurnal penyesuaian dikelas $\mathrm{X}$ AKKL 2 SMK Negeri 1 Yogyakarta tahun pelajaran 2019/2020. Yogyakarta: Universitas sanata dharma https://repository.usd.ac.id/3785/

Astini, N. K. S. (2020). Tantangan dan peluang pemanfaatan teknologi infromasi dalam pembelajaran online masa covid-19. Jurnal Online of cetta, 03 (2): 1-14. 
https://jayapanguspress.penerbit .org/index.php/cetta/article/vie $\mathrm{w} / 452$

Darwis M. (2017). Belajar Dan Pembelajaran, IAIN Padangsidimpuan, 3, (2): 4560. http://jurnal.iainpadangsidimpuan.ac.id/index. php/F/article/view/945/0

Irawati, M. (2018). Profil minat \& hasil belajar siswa dalam pembelajaran matematika kelas VIII SMP Negeri 5 Yogyakarta pada pokok bahasan penyajian data dengan menggunakan media pembelajaran kahoot. Skripsi. Yogyakarta : Universitas Sanata Dharma.http://ejournal.unp.ac.id/ students/index.php/pmat/article/v iew/10555

Irnaningtyas. (2015). BIOLOGI untuk SMA/MA Kelas X Kelompok Peminatan Matematika dan Ilmu Alam. Bandung: Erlangga.

Mamin, R \& Arif, N. (2018). Efektivitas media pembelajaran video tutorial terhadap hasil belajar mahasiswa pada matakuliah ipa sekolah. Jurnal prosiding edisi 5.

https://ojs.unm.ac.id/semnaslem lit/article/view/8975

Mulyani, W. (2013). Pengaruh pembelajaran berbasis elearning terhadap hasil belajar siswa pada konsep implus dan momentum. Skripsi. Jakarta : Universitas Islam Negeri Syarif Hidayatullah.

https://repository.uinjkt.ac.id/ds pace/bitstream/123456789/2623

\section{2/3/WIWI\%20MULYANI-} FITK.pdf

Rianingtias, O. (2019). Pengembangan game edukasi berbasis android sebagai media pembelajaran biologi bernuansa motivasi siswa kelas XI di SMA/MA. Lampung: Universitas Islam Negeri Raden Intan.

http://repository.radenintan.ac.id/ 6304/

Rigianti, H. A. (2020). Kendala pembelajaran daring guru sekolah dasar di kabupaten banjarnegara. Online Jurnal Of Elemntry School, 07. Nomor 02. https://journal.upy.ac.id/index.p hp/es/article/view/768

Slameto. (2010). Belajar dan FaktorFaktor yang Mempengaruhinya. Jakarta: Rineka Cipta.

Sugiyono. (2014). Metode Penelitian Kuantitatif, Kualitatif, Dan $R \& D$. Bandung: Alfabet, CV.

Sugiyono. (2015). Metode Penelitian Pendidikan. . Bandung: Alfabet, CV.

Unik H.S, Iefone S.H, Isti L.A, Nur A.I, Salsabila D. (2020). Pemanfaatan aplikasi quizizz sebagai media pembelajaran ditengah pandemi pada siswa SMA. Jurnal Ilmiah Ilmu Terapan Universitas Jambi, 4(2):1-14 https://onlinejournal.unja.ac.id/JIITUJ/article /view/11605

Yoselia, A. K. (2020). Efektivitas penggunaan aplikasi quizizz. dalam pembelajaran daring (online) fisika pada materi usaha 
\& energi kelas X Mipa di SMA

Masehi Kudus tahun pelajaran

2019/2020. Skripsi. Yogyakarta:

Universitas

Sanata

Dharma.https://repository.usd.a

c.id/37682/

Solikah, H. (2020). Pengaruh penggunaan media pembelajaran interaktif quizizz terhadap motivasi dan hasil belajar siswa pada materi teks persuasif kelas VIII di SMPN 5

Sidoarjo Tahun pelajaran 2019/2020.https://jurnalmahasis wa.unesa.ac.id/index.php/bapal a/article/view/34508 